\title{
Bacterial Protein
}

National Cancer Institute

\section{Source}

National Cancer Institute. Bacterial Protein. NCI Thesaurus. Code C16319.

Proteins that orig inated from bacteria sources. 